学術論文

\title{
磁粉探傷試験におけるき裂の定量的評価に向けた 付着磁粉の動画像計測と漏洩磁束密度の評価
}

\section{Measurement of Magnetic Particle Amount and Evaluation Magnetic Flux Leakage Density for Quantitative Evaluation in Magnetic Particle Testing}

\author{
福岡 克弘 ${ }^{* 1}$ (正員), 川越 一平 ${ }^{* 1}$
}

Katsuhiro FUKUOKA (Mem.), Ippei KAWAGOE

\begin{abstract}
Because magnetic particle testing (MT) can detect microcracks by a simplified method, it is applied in non-destructive inspections of ferromagnetic materials in various industrial fields. Recently, establishing a technology that quantitatively evaluates crack shapes as well as detects cracks with high-precision has become an important topic in the non-destructive inspection. We consider developing such a quantitative evaluation technique that employs magnetic particle pattern of a crack in MT. In this research, the process of magnetic particle adherence to a crack was observed with a high-speed video camera and the change in the magnetic particle amount was evaluated at each instant. In addition, the technique for evaluating small magnetic flux leakage (MFL) density accurately was discussed with the measurement and the numerical analysis. From these results, the relationship between the MFL density and the magnetic particle amount was evaluated.
\end{abstract}

Keywords: magnetic particle testing, quantitative evaluation, magnetic flux leakage (MFL), finite element method, dynamic image

\section{1. はじめに}

非破壊検査における磁粉探傷試験は，強磁性材料に 存在する極微小なき裂を検出できることから，鉄鋼製 品の品質検査において広く用いられている。非破壊検 査において, 検出されたき裂の構造強度一の影響を判 断することは重要であり, そのためにはき裂の形状を 定量的に評価する必要がある。しかし, 現状の磁粉探 傷試験においては, き裂の有無の判断とその分布形状 を大まかに把握する検査に留まっており，未だ定量的 な評価手法は確立されていない。

そこで我々は, き裂への付着磁粉量の評価と, き裂 からの漏洩磁束密度分布の評価により, 磁粉探傷試験 におけるき裂の定量的評価手法の確立を検討してきた。 先行研究において, A 形標準試験片 $[1,2]$ を用いた試験 体における付着磁粉量の評価, およびき裂周辺部にお ける鋼板内外の磁束密度分布を数值解析により評価し た[3-5]。しかし，A 形標準試験片を用いた評価では， 電磁軟鉄（純鉄）にき裂が加工された A 形標準試験片 を, 冷間圧延鋼板 SPCC に貼り付けた試験体を用いた ため, 鋼板と A 形標準試験片の材料特性は大きく異な っていた。き裂の形状と, 磁粉模様および漏洩磁束密 度の相関関係を把握するには，直接鋼板にき裂を施し

連絡先:福岡克弘 $\bar{\top} 522-8533$ 滋賀県彦根市八坂町 2500 滋賀県立 大学 工学部 電子システム工学科 E-mail : fukuoka.k@usp.ac.jp ${ }^{* 1}$ 滋賀県立大学
た試験体での評価が必要である。

本研究では, 深さをパラメータにしたき裂を鋼板表 面に加工し，それを試験体としてき裂形状と付着磁粉 量の関係を明らかにした。また，ホール素子を用いた 3 方向成分の漏洩磁束密度の計測と, 有限要素法を用 いた数值解析を組み合わせることにより，実験では評 価が困難な, 微小き裂からの微量な漏洩磁束密度を正 確に評価する手法を検討した。これらの結果より，き 裂に付着する磁粉量と漏洩磁束密度の関係を評価した。

\section{2. 高速度カメラを用いた付着磁粉量の動画像計測}

き裂の形状と付着磁粉量の関係を明らかにするた め, 極間法[1]による磁粉探傷試験を対象として, 探傷 試験中のき裂部に, 磁粉が付着する過程を動画像計測 した。Fig.1 に測定システムを示す。動画像計測は高速 度ビデオカメラ（キーエンス：VW-6000）を用いた。

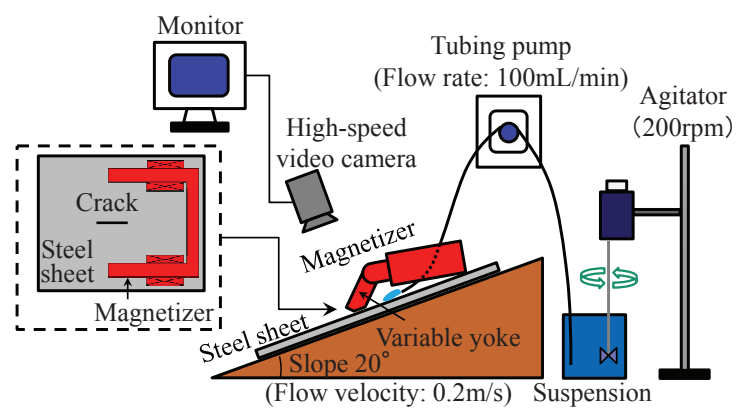

Fig. 1 Layout of the test object and magnetizer. 


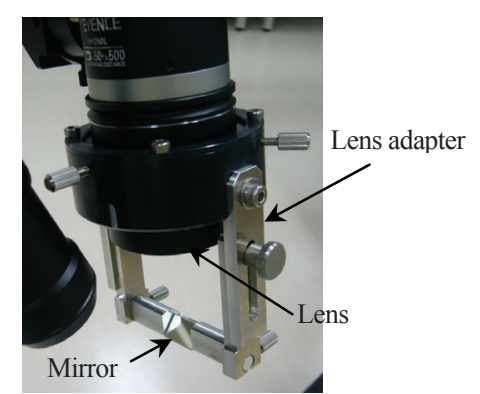

Fig. 2 Lens adaptor for side surface observation.

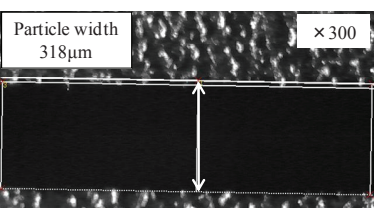

(a) Upper surface observation

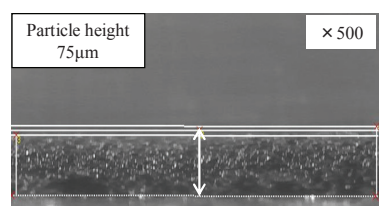

(b) Side surface observation
Fig. 3 Observation of adhesion magnetic particles.

レンズは 200〜500 倍を使用し, シャッタースピードは $1 / 500 \mathrm{~s}$, フレームレートは $250 \mathrm{fps}$ とした。磁化器（電 子磁気工業 : Um-5BF）の磁極間距離は $165 \mathrm{~mm}$ で，磁 極の断面形状は $25 \mathrm{~mm} \times 25 \mathrm{~mm}$ のものを使用した。磁 化コイルの巻き数は 820 ターンである。励磁電流は周 波数 $60 \mathrm{~Hz}$ の $2.25 \mathrm{~A}_{\mathrm{rms}}\left(100 \mathrm{~V}_{\mathrm{rms}}\right.$ 印加時の電流 $)$ とした。

試験鋼板は，冷間圧延鋼板 SPCC $(300 \mathrm{~mm} \times 400 \mathrm{~mm}$ $\left.\times 1 \mathrm{~mm}^{\mathrm{t}}\right)$ の表面に，放電加工によりき裂を加工した。 き裂の長さを $6 \mathrm{~mm}$, 幅を $100 \mu \mathrm{m}$ 一定とし, 深さをパ ラメータにした 8 体の試験体を作製し, き裂深さと付 着磁粉量の関係を評価した。ここで，作製した試験体 の実際のき裂深さを, レーザー変位計（キーエンス： LK-H020）を用いて測定すると, 加工の目標き裂深さ (50, 70, 100, 150, 200, 300, 400, $500 \mu \mathrm{m})$ から誤差があ り，それぞれの実測值は 43, 70, 92, 140, 170, 220, 400, $480 \mu \mathrm{m}$ であった。本論文では，き裂深さの実測值を 用いて関係を評価する。検出媒体は湿式とし, 粒度 1 3 $\mu \mathrm{m}$ の黒色磁粉 (二酸化鉄) を水に分散し, 磁粉濃度 を $2 \mathrm{~g} / \mathrm{L}$ とした磁粉液 (検査液) を用いた。試験鋼板を 傾斜角度 $20^{\circ}$ のスロープに固定することで, 磁粉液の 流速を $0.2 \mathrm{~m} / \mathrm{s}$ 一定とした。また, 流量を一定とするた めチュービングポンプを用いて磁粉液を適用し, $100 \mathrm{~mL} / \mathrm{min}$ とした。試験鋼板への磁化を開始した後, 磁粉液を 12 秒間適用した。き裂に磁粉が付き始めた時 間を 0 秒とし, 付着磁粉の観測は 20 秒間の評価とした。 試験体の磁化は連続法[1]により行い, 試験中は磁化器 への通電を続けた。

試験鋼板の上部に高速度カメラを設置して撮影す

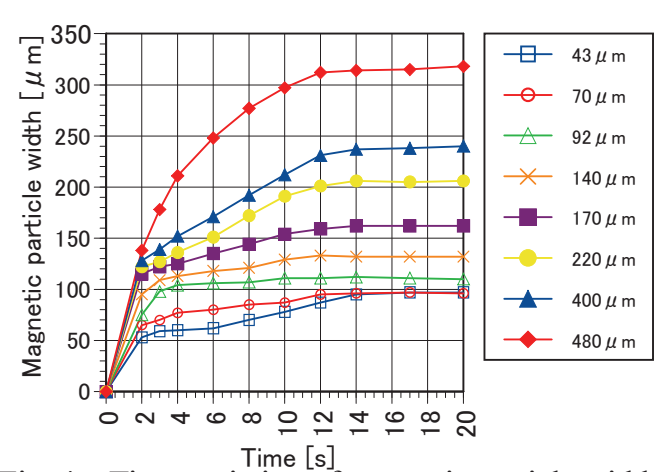

Fig. 4 Time variation of magnetic particle width.

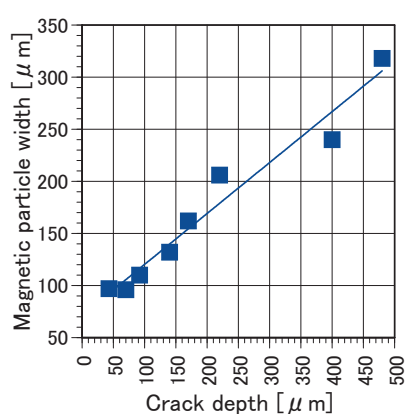

(a) Magnetic particle width

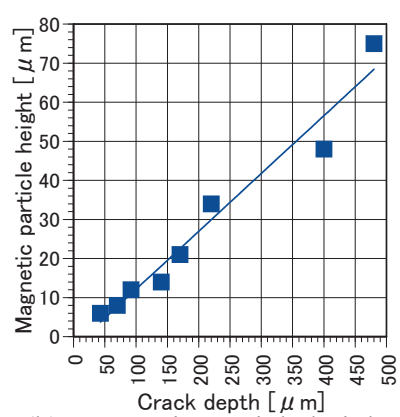

(b) Magnetic particle height

Fig. 5 Relationship between crack depth and magnetic particle amount.

るため, 磁化器には可変ヨークを取り付け, 鋼板上に 寝かせた状態で試験した。これまでの研究により，鋼 板上に磁化器を寝かせて設置しても, 磁化器ヨークか ら試験鋼板への漏れ磁束はほとんどなく，探傷試験に は影響がないことを確認している[6]。き裂の位置は磁 化器の磁極を結ぶ直線上の中央とし，磁化方向がき裂 の長手方向に直交するように磁化器を配置した。き裂 に付着する磁粉を上面と側面からそれぞれ観察し, 磁 粉の幅と高さを計測することで，付着磁粉量を評価し た。側面観察では，実験機器の配置の関係上，試験体 の側面にカメラを配置して撮影することは困難であっ た。そこで, Fig.2に示す側面観察用のレンズアダプタ を作製し，ミラーの反射を利用することにより，鋼板 の上部に配置したカメラからの側面撮影を可能とした。

Fig.3 は, 磁粉の付着過程を撮影した動画像から, 静 止画を抽出した一例である。これらの画像から，き裂 に付着する磁粉の幅 (Fig.3(a)) と高さ（Fig.3(b)）を評 価する。観測時間の 20 秒間における各時点での画像か ら, 各き裂での磁粉付着過程における磁粉幅の時間変 化を評価して Fig.4 に示す。この図から，き裂に付着 する磁粉の増加割合は, き裂の深さにより変化し, き 裂が深いほど磁粉幅は急峻に増加することが判る。ま た，最終的にき裂に付着する磁粉の幅も広くなる。

ここで, 磁粉付着過程おける磁粉高さの計測は, 磁 


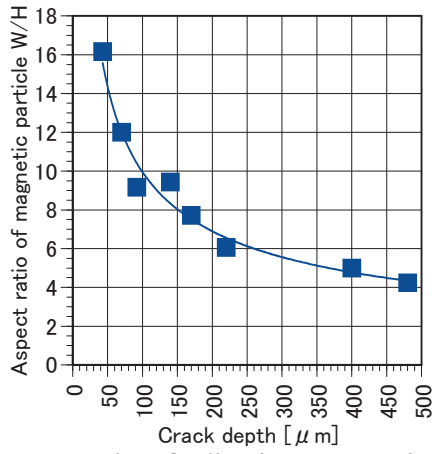

Fig. 6 Aspect ratio of adhesion magnetic particles.

粉夜の流れにより焦点距離が変化し, カメラのピント がずれるため, 動画像での撮影は困難であった。そこ で，磁粉液の流れが止まった後の，20 秒時点における 最終的な付着磁粉の幅および高さから, き裂深さと付 着磁粉量の関係を評価した。その結果を Fig.5 に示す。

Fig.5 より, き裂が深くなると, 磁粉の幅と高さはとも に比例関係で増加することが判る。そこで，き裂深さ を $D$, 磁粉幅を $W$, 磁粉高さを $H$ とし, き裂深さと付 着磁粉量の関係式を求めた。き裂深さと磁粉幅の関係 は $D=1.9 W-132$ となり, き裂深さと磁粉高さの関係 は $D=6.5 H+25$ と表せる。この両式をまとめると $D=$ $\{(1.9 W-132)+(6.5 H+25)\} \div 2$ となり, 磁粉の幅と高さ の測定值から，き裂の深さを推定することができる。 今後, き裂の長さと幅をパラメータにして付着磁粉量 を確認し, き裂形状と付着磁粉量の関係を詳細に評価 する予定である。

各き裂における付着磁粉の幅と高さの割合 $W / H$ (ア スペクト比と呼ぶ）を Fig.6 に示す。き裂の深さによ り，アスペクト比が異なることが判る。浅いき裂では 磁粉は低く付着し, き裂が深くなるほど高さ方向に付 着する磁粉の割合が多くなることが確認された。今後, 鋼材の種類や熱処理条件を変えた試験体を作製し, 付 着磁粉のアスペクト比が, 鋼材の種類に依存するかを 検討していく。

\section{3 方向成分の漏洩磁束密度計測}

磁粉探傷試験において, 磁粉はき裂からの漏洩磁束 による磁気力（吸引力）を起因として，き裂周辺部に 付着する。この磁気力は, 漏洩磁束密度の強度および 分布（傾き）により決定されるため, き裂の形状によ りそれらが変化すると, 付着磁粉量も変化する。した がって, 付着磁粉量からき裂形状を定量的に評価する には, き裂からの漏洩磁束密度の強度に加え, その分 布形状を詳細に把握することが重要となる。そこで,

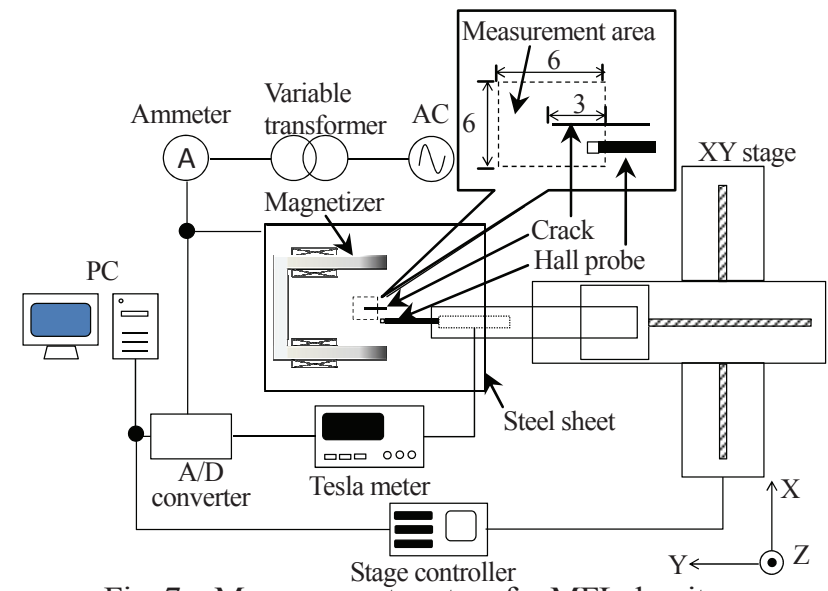

Fig. 7 Measurement system for MFL density.

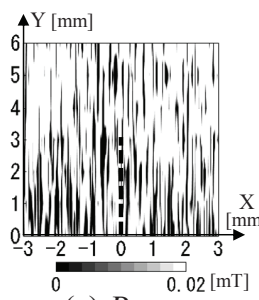

(a) $B_{\mathrm{X}}$

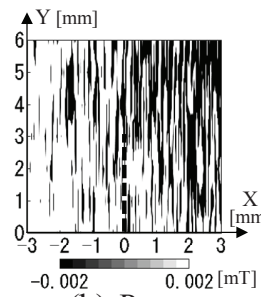

(b) $B_{\mathrm{Y}}$

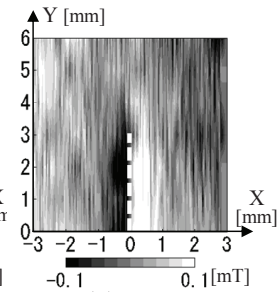

(c) $B_{\mathrm{Z}}$
Fig. 8 MFL density in $43 \mu \mathrm{m}$ depth.

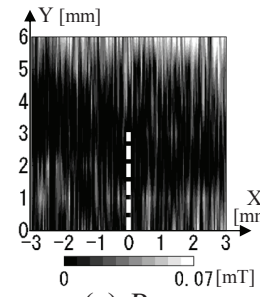

(a) $B_{\mathrm{X}}$

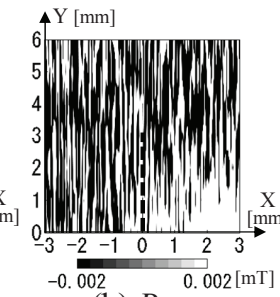

(b) $B_{\mathrm{Y}}$

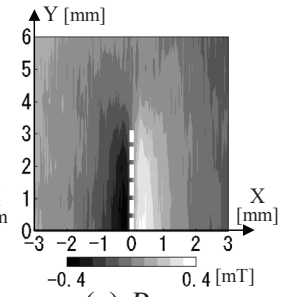

(c) $B_{\mathrm{Z}}$
Fig. 9 MFL density in $92 \mu \mathrm{m}$ depth.

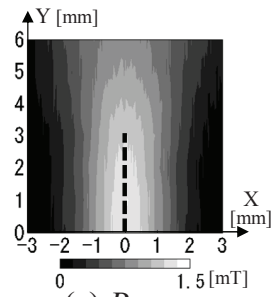

(a) $B_{\mathrm{X}}$

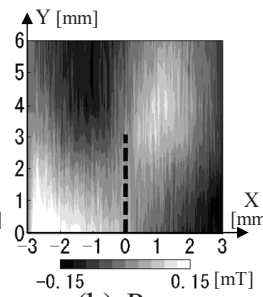

(b) $B_{\mathrm{Y}}$

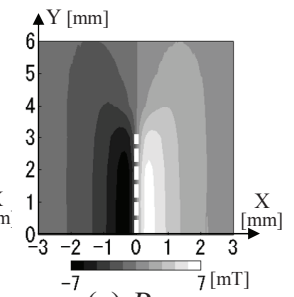

(c) $B_{\mathrm{Z}}$
Fig. 10 MFL density in $480 \mu \mathrm{m}$ depth.

き裂周辺部における漏洩磁束密度の 3 方向成分 $\left(B_{\mathrm{X}}, B_{\mathrm{Y}}\right.$, $B_{\mathrm{Z}}$ ）を，ホール素子を用いて測定した。測定システム を Fig.7 に示す。付着磁粉量の動画像計測で用いた試 験体の中から，き裂深さ $43,92,480 \mu \mathrm{m}$ における漏洩 磁束密度を測定した。磁化器の配置と励磁電流は, 動 画像計測と同条件とした。3 軸ホール素子プローブを $\mathrm{XY}$ 精密ステージ（中央精機 : ALD-230-C2P) に固定 し, 鋼板表面上を 2 次元スキャンした。ホール電圧は, 
テスラメータ（電子磁気工業 : GM-5307）により磁束 密度に変換し, その出力を $\mathrm{A} / \mathrm{D}$ 変換してコンピュータ に取り込んだ。各ホール素子のアクティブエリアは 50 $\mu \mathrm{m} \times 50 \mu \mathrm{m}$ である。 $\mathrm{A} / \mathrm{D}$ 変換のサンプリング周波数 を $6 \mathrm{kHz}$ とし, 各測定点において 1 周期 $(60 \mathrm{~Hz}), 100$ 点のデータを収集した。XY ステージはパソコンによ り制御し，測定範囲と測定間隔を決定した。き裂の幅 方向を $\mathrm{X}$, 長手方向を $\mathrm{Y}$ と, き裂の中心を原点とし た。X 方向はき裂を中心に $6 \mathrm{~mm}( \pm 3 \mathrm{~mm}), \mathrm{Y}$ 方向は き裂の中心から上半分 $(3 \mathrm{~mm})$ を含む $6 \mathrm{~mm}$ を測定範 囲とした。測定間隔はX 方向に $40 \mu \mathrm{m}, \mathrm{Y}$ 方向に $1 \mathrm{~mm}$ とした。 X と Y 方向成分の磁束密度を測定するホール 素子は, 鋼板表面に対して垂直に配置する必要がある ため, ホール素子と試験鋼板とのギャップ（リフトオ フ)は, Xと Y 方向を $1.6 \mathrm{~mm}, \mathrm{Z}$ 方向を $0.4 \mathrm{~mm}$ とした。

Fig.8 10 に示すのは, 実深さ $43,92,480 \mu \mathrm{m}$ の各き 裂における X, Y, Z 方向の漏洩磁束密度分布である。各 方向成分において, 磁束密度が最大となる位相での結 果を示した。ここでは, き裂からの漏洩磁束密度のみ を評価するため, き裂のない状態において鋼板上の空 間の磁束密度を測定し, き裂の存在する状態での測定 結果からき裂のない状態の結果を減算した。各図にお いてき裂の位置を破線で示す。

Fig.8, 9 のき裂深さ $43 \mu \mathrm{m}$ および $92 \mu \mathrm{m}$ の試験体で は, 鋼板表面に垂直方向の漏洩磁束密度 $B_{\mathrm{Z}}$ は観測され るものの, 水平方向の $B_{\mathrm{X}}, B_{\mathrm{Y}}$ は值が小さいため, ノイ ズに埋もれ観測されないことが判る。本実験において $B_{\mathrm{Z}}$ 方向の从が観測されたのは, $\mathrm{Z}$ 方向のホール素子の リフトオフが X,Y 方向より小さく, 鋼板に近い位置で の磁束密度が観測されているためである。鮮明に観測 される $B_{Z}$ の分布を見ると, き裂の長手方向にき裂を挟 み込むように正負の磁束密度分布となることが判る。

Fig.10のき裂深さが $480 \mu \mathrm{m}$ の試験体では, 全方向 の漏洩磁束密度が観測される。き裂の長手方向に垂直 で, 鋼板表面に水平な成分の $B_{\mathrm{X}}$ は, き裂の中央部で最 大となる。き裂の長手方向に平行で鋼板表面に水平な 成分の $B_{\mathrm{Y}}$ では, き裂の長手方向にき裂部を迁回寸る磁 束が鋼板中に生じ，その磁束が漏洩することにより， き裂の端部において, き裂の両側に正負の漏洩磁束密 度が観測される。また, 各き裂深さでの $B_{\mathrm{Z}}$ を比較する と，き裂が深くなるほど増加することが判る。

\section{4. 数值解析による漏洩磁束密度分布の詳細評価}

水平成分を測定するホール素子を鋼板表面近傍に配

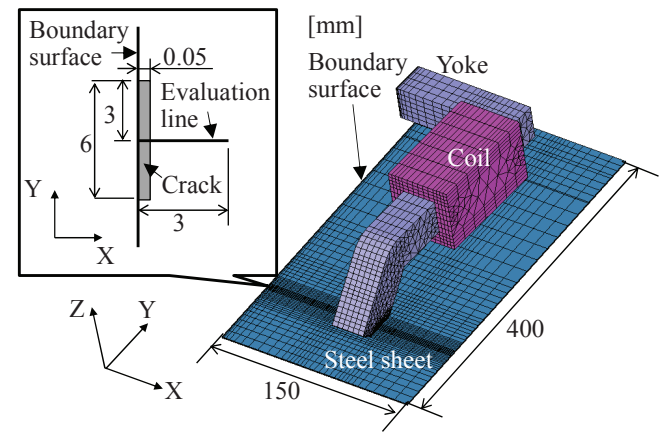

Fig. 11 Analytical model.

置することは難しく, 微小き裂からの漏洩磁束密度 $B_{\mathrm{X}}$, $B_{\mathrm{Y}}$ を評価することは困難であった。磁気センサに，木 ール素子よりも高感度な MI 素子やフラックスゲート 等を用いることも考えられるが，動作範囲内で空間分 解能と感度を両立させ測定するには限界がある。そこ で, 有限要素法を用いた数值解析により, 測定が困難 であった微小き裂からの微量な漏洩磁束密度の評価を 検討した。数值解析モデルをFig.11 に示す。試験鋼板, 磁化器およびき裂のそれぞれの中央面に境界条件（自 然境界）を設けて，1/2 形状の解析モデルとした。解 析における磁化器, 試験鋼板および励磁電流は, 前述 の実験と同じ条件に設定した。き裂の形状も, 実験で 用いた試験体と同形状に設定し，き裂深さをパラメー タにしてモデルを作製した。解析における試験鋼板の 導電率は $6 \times 10^{6} \mathrm{~S} / \mathrm{m}$ とした。磁化器ヨークは積層鋼板 であるため, 渦電流は発生しないとして導電率を $0 \mathrm{~S} / \mathrm{m}$ とした。磁化器ヨークと試験鋼板の間には, 鋼板表面 の粗さによる接触状態を考慮して $0.1 \mathrm{~mm}$ のギャップ を設けた。要素数は 431,413 , 節点数は 386,988 とした。

本論文における数值解析では, 漏洩磁束密度分布を 詳細に評価するのが目的である。よって，き裂周辺部 の要素分割を細かくする必要があり，モデル全体の要 素数および節点数が多くなった。そこで，計算機スペ ックの制限と解析時間の短縮のため，等価正弦波を用 いた交流非線形解析[2]を行った。この手法では, j $\omega$ 法 による周波数応答解析において, 磁極ヨークと試験鋼 板のそれぞれの $B-H$ 曲線を用いて, 磁束密度の正弦波 強度を決定する。これにより，簡易的に磁性体の非線 形磁化特性を模擬する。なお，ステップバイステップ 法による過渡応答解析と本手法との解析解の誤差は, 鋼板内部の磁束密度が $0.3 \%$, 鋼板直上の空間の磁束密 度が 1.6\%であり, 問題のないことを確認している。

一般的に低炭素鋼では，材料成分比や製造・加工工 程履歴の差から，種類や熱処理条件が同じ材料であっ 


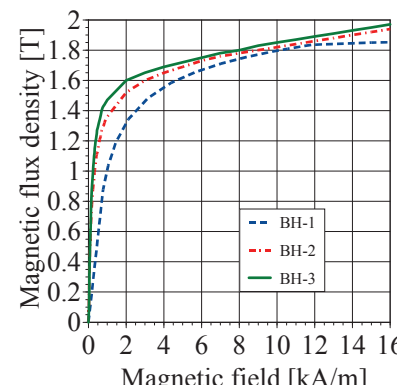

(a) $B$ - $H$ curves

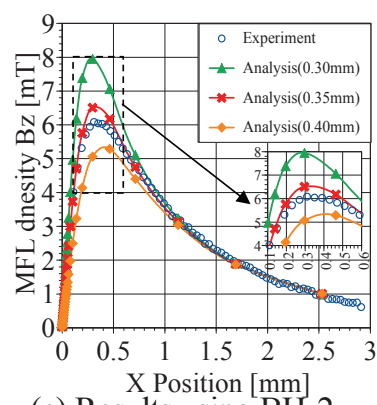

(c) Results using BH-2

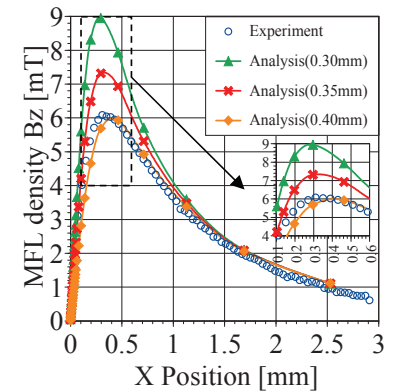

(b) Results using BH-1

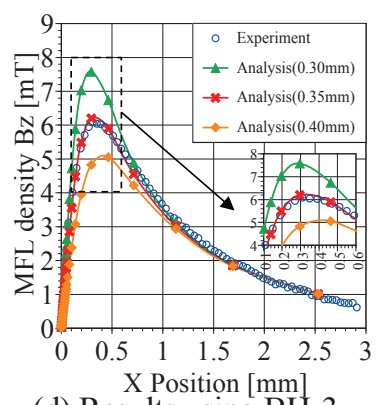

(d) Results using $\mathrm{BH}-3$

Fig. 12 Comparison between analytical and experimental results in each $B-H$ curves.

ても， $B-H$ 曲線には違いが生じる。したがって，微小 き裂から発生する微小な漏洩磁束密度を正確に評価す るためには，実験で用いた材料に合った $B-H$ 曲線を， 解析モデルに与える必要がある。そこで, Fig.12(a)に 示寸 3 種類の SPCC の $B-H$ 曲線を用いて解析を行い, 実験結果との比較により妥当な $B-H$ 曲線を決定した。

また，前述の実験において，ホール素子の鋼板から のリフトオフは, $\mathrm{X}$ と $\mathrm{Y}$ 方向を $1.6 \mathrm{~mm}, \mathrm{Z}$ 方向を $0.4 \mathrm{~mm}$ に設定したが，実験においてリフトオフを $0.05 \mathrm{~mm}$ 以 下のオーダで正確に位置決めすることは困難である。

しかし, 漏洩磁束密度の值およびその分布形状は, 試 験鋼板からのリフトオフが変われば大きく異なるため

(Fig.12 参照), 実験と解析の結果を比較するには, リ フトオフ（鋼板からの評価位置）を正確に一致させる 必要がある。そこで, 解析結果での各リフトオフにお ける漏洩磁束密度の分布を, 実験結果と比較すること により, 正確なセンサのリフトオフも同時に評価した。

Fig.12(a)の各 $B-H$ 曲線における解析結果を実験結果 と比較して Fig.12(b)〜(d)に示す。ここでは, き裂深さ $480 \mu \mathrm{m}$ における漏洩磁束密度 $B_{Z}$ の線分布により評価 した結果（ $B_{Z}$ 成分が最大となる位相）を示す。Fig.11 の解析モデル図で，き裂の長手方向の中央 $(\mathrm{Y}=0 \mathrm{~mm})$ において，き裂の幅方向の中心を $0 \mathrm{~mm}$ とし，き裂の 幅方向（X 方向）に $3 \mathrm{~mm}$ の間を評価した。評価ポジ ションを横軸とし，き裂のエッジは $0.05 \mathrm{~mm}$ （き裂幅：
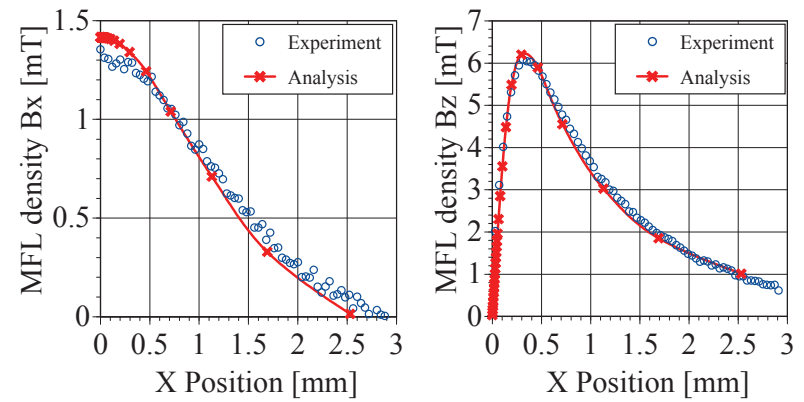

(a) $B_{\mathrm{X}}$ (Liftoff: $\left.1.70 \mathrm{~mm}\right)$

(b) $B_{\mathrm{Z}}$ (Liftoff: $0.35 \mathrm{~mm}$ )

Fig. 13 Line distribution of MFL density in $480 \mu \mathrm{m}$ depth.

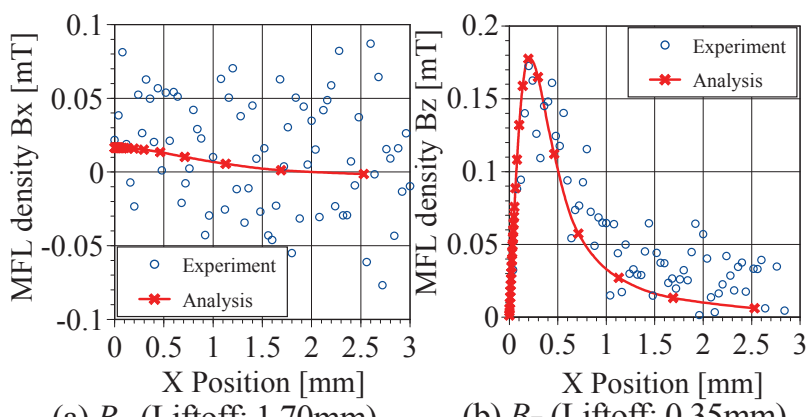

(a) $B_{\mathrm{X}}$ (Liftoff: $1.70 \mathrm{~mm}$ )

(b) $B_{\mathrm{Z}}$ (Liftoff: $0.35 \mathrm{~mm}$ )

Fig. 14 Line distribution of MFL density in $43 \mu \mathrm{m}$ depth.

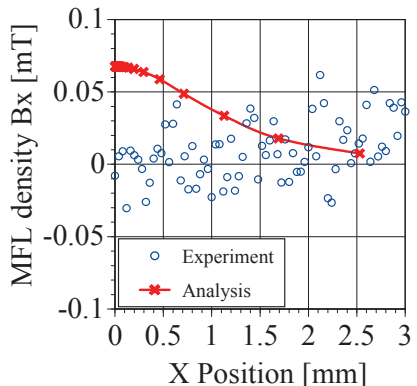

(a) $B_{\mathrm{X}}$ (Liftoff: $\left.1.75 \mathrm{~mm}\right)$

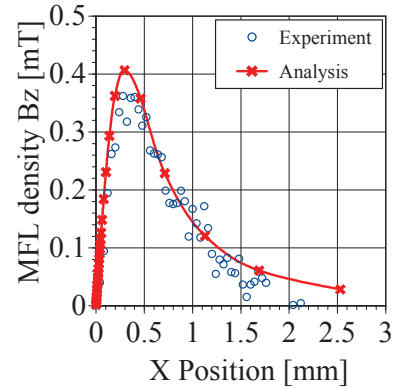

(b) $B_{\mathrm{Z}}$ (Liftoff: $0.40 \mathrm{~mm}$ )
Fig. 15 Line distribution of MFL density in $92 \mu \mathrm{m}$ depth.
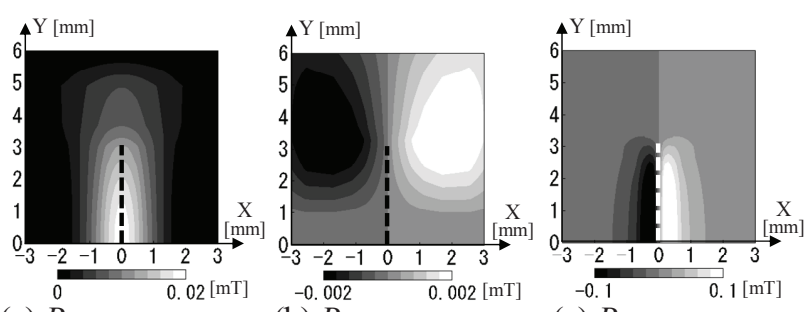

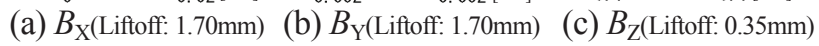

Fig. 16 Analytical results in $43 \mu \mathrm{m}$ depth.

$0.1 \mathrm{~mm} ）$ に位置する。実験結果は, Fig.10の 2 次元分 布から, 解析結果と同位置での線分布を抽出して示し た。Fig.12(b)〜(d)より, 同じ B- $H$ 曲線の結果において, リフトオフの違いによる解析結果を比較する。リフト オフが高くなるほど, 漏洩磁束密度のピーク值は小さ くなり，またそのピークはき裂から離れた位置で観測 
される。つまり, リフトオフが変わると, 漏洩磁束密 度の值に加え，その分布形状も変化することが判る。 次に, 同じリフトオフの位置において, $B-H$ 曲線の違 いによる解析結果を比較すると, 漏洩磁束密度の值は 異なるが，その分布形状は同じであることが判る。こ れらの結果から, Fig.12(d)の BH-3 の B- $H$ 曲線を用い て解析した結果で，リフトオフが $0.35 \mathrm{~mm}$ の結果が, 最も実験結果と一致することが判る。したがって, 実 験で用いた試験鋼板の $B-H$ 曲線はBH-3 だと判断でき, 以降の解析には BH-3 の曲線を用いる。また, 実験で の試験鋼板と $B_{\mathrm{Z}}$ 測定用ホール素子とのリフトオフは $0.35 \mathrm{~mm}$ であったと判断でき, 本手法により, 実験に おける漏洩磁束密度のセンシング位置を, 正確に推定 可能であることも確認した。

同様にして, $B_{\mathrm{X}}$ 成分における試験鋼板とホール素子 とのリフトオフも評価し(評価の結果 $1.70 \mathrm{~mm}$ であっ た), き裂深さ $480 \mu \mathrm{m}$ における漏洩磁束密度 $B_{\mathrm{X}}$ と $B_{\mathrm{Z}}$ の解析結果を実験結果と比較して Fig.13 に示寸。

Fig.13(a), (b)から， $B_{\mathrm{X}}$ と $B_{\mathrm{Z}}$ はともに実験と解析でよく 一致している。これらの結果から, 開発した数值解析 モデルおよび評価手法が妥当であると判断できる。

本解析モデルにより, き裂深さ $43,92 \mu \mathrm{m}$ における 漏洩磁束密度 $B_{\mathrm{X}}, B_{\mathrm{Z}}$ を評価した。Fig.14, 15 に解析結果 と実験結果を示す。実験では観測できなかったき裂深 さ $43,92 \mu \mathrm{m}$ の $B_{\mathrm{X}}$ 成分が, 解析により評価可能であ ることが確認される。Fig.13〜15 において， $B_{X}$ 成分は き裂幅の中央部でピークになり, 深いき裂ほどその值 は大きくなる。しかし, 各き裂において, $B_{\mathrm{X}}$ は $\mathrm{X}=$ $2.5 \mathrm{~mm}$ の位置から立ち上がり始め, き裂の深さによる 差はない。つまり, その分布形状を比較すると, 深い き裂ほど傾きが急峻となることが確認される。次に, $B_{Z}$ 成分に着目寸ると，き裂のエッジ $(X=0.05 \mathrm{~mm})$ か ら少し離れた位置でピークとなり, 深いき裂ほどその 值は大きくなることが判る。 $B_{Z}$ の分布形状は, き裂が 浅いほど細くシャープな分布となる。つまり, き裂深 さと漏洩磁束密度の傾きの関係は, $B_{\mathrm{X}}$ とは逆（浅い傷 ほど $B_{Z}$ の傾きは急峻）になる。実験結果の Fig.8 に対 応寸る解析結果を Fig.16 に示寸。 $B_{\mathrm{Y}}$ 成分の值は, $B_{\mathrm{X}}$ の約 $1 / 10, B_{Z}$ の約 $1 / 50$ と非常に小さいが評価されてお り, き裂深さ $43 \mu \mathrm{m}$ の微小き裂においても, 全方向の 漏洩磁束密度が詳細に評価できることが確認される。

本手法により，実験では測定が困難な微小き裂から の微量な漏洩磁束密度を, 簡便な手法で正確に評価で きることを確認した。

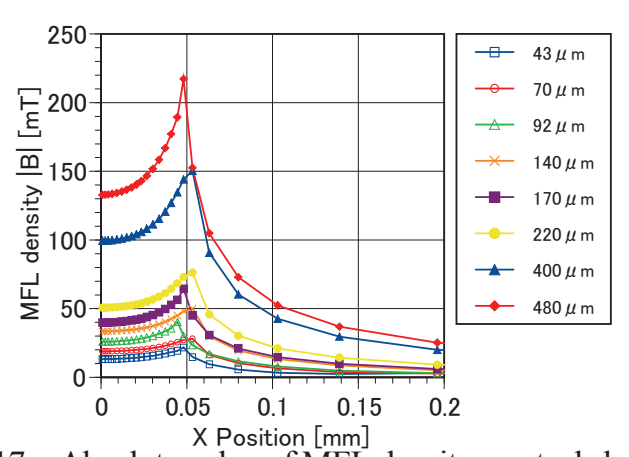

Fig. 17 Absolute value of MFL density on steel sheet.
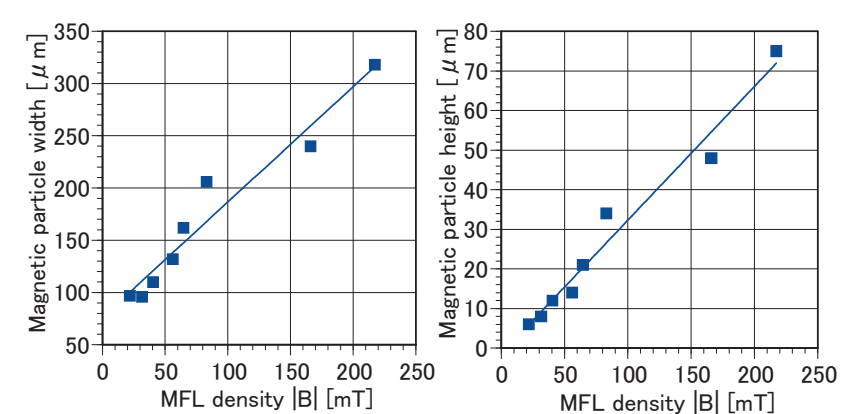

(a) Magnetic particle width

(b) Magnetic particle height

Fig. 18 Relationship between strength of MFL density and magnetic particle amount.
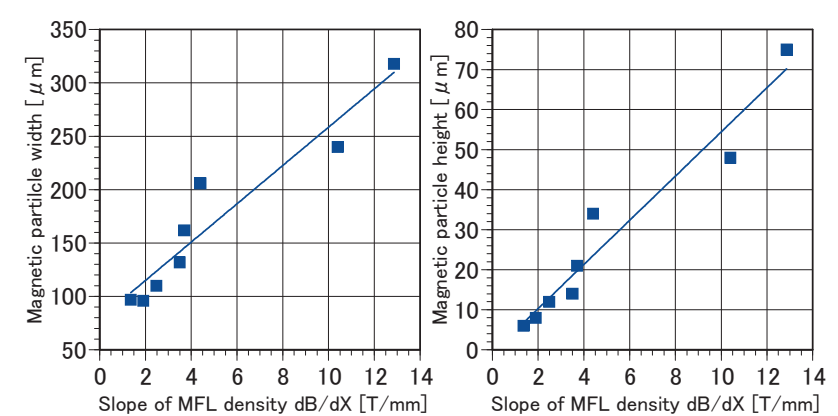

(a) Magnetic particle width

(b) Magnetic particle height

Fig. 19 Relationship between slope of MFL density and magnetic particle amount.

\section{5. 付着磁粉量と漏洩磁束密度の関係評価}

Fig.17 に，4 章で検討した解析モデルを用いて，き裂 の深さを 43, 70, 92, 140, 170, 220,400, $480 \mu \mathrm{m}$ と変化さ せ解析した漏洩磁束密度の線分布を示寸。ここで示す 漏洩磁束密度は, $B_{\mathrm{X}}, B_{\mathrm{Y}}, B_{\mathrm{Z}}$ の 3 方向成分の絶対值 $|B|$ である。鋼板直上のリフトオフ $5 \mu \mathrm{m}$ を評価位置とし た。鋼板直上における漏洩磁束密度の絶対值 $|B|$ は, き 裂のエッジ（X=0.05mm 付近）でピークとなることが 判る。 $|B|$ の分布形状に着目すると, 深いき裂ほど傾き が急峻となる。4 章において， $B_{\mathrm{X}}$ の傾きは深いき裂ほ ど， $B_{Z}$ の傾きは浅いき裂ほど急峻となることを確認し た。したがって, $|B|$ の傾きは $B_{\mathrm{X}}$ の方が支配的となるこ 
とが判る。なお，各き裂深さでピークの位置に差があ るのは, 実験で用いた試験体のき裂幅の実寸法にて, 解析モデルのき裂を作製したためである。この分布か ら $|B|$ のピーク值を読み取り, 漏洩磁束密度の強度と付 着磁粉量との関係を考察した。その結果を Fig.18 に示 す。また, 磁粉がき裂に付着する際の磁気力は, 漏洩 磁束密度の強度に加え, その傾きにも影響を受けると 考えられる。そこで, Fig.17 の漏洩磁束密度 $|B|$ の線分 布から傾きを求め, 付着磁粉量との関係を評価した結 果を Fig.19 に示す。漏洩磁束密度の傾きは, 最も急峻 な傾きとなるピーク值の右側近傍で評価した。これら の結果より, 付着磁粉量（磁粉の幅と高さ）は, き裂 からの漏洩磁束密度の強度および傾きにそれぞれ比例 することが確認された。

き裂が深くなると, 漏洩磁束密度の強度および傾き は, Fig.17 に示すように比例して増加し, 磁粉に働く 磁気力が増える。そのため, 漏洩磁束密度の強度およ び傾きと, 付着磁粉量は比例する。したがって, き裂 深さと付着磁粉量が比例した 2 章で述べた現象は, 妥 当なものと考察される。ただし, Fig.17の漏洩磁束密 度分布から判るように, き裂深さをパラメータにした 評価においては, 漏洩磁束密度の強度が大きくなれば その傾きも同時に急峻になる。今後, き裂幅と長さに ついても検討し, 漏洩磁束密度の強度が一定で, 傾き のみ変化するき裂形状の条件下において詳しく関係を 評価する予定である。

\section{6. まとめ}

磁粉探傷試験におけるき裂形状の定量的な評価手 法の確立を目的として, き裂深さと付着磁粉量の関係 を評価した。また，実験と解析を組み合わせたき裂か らの漏洩磁束密度分布の評価手法を検討した。これら により, 付着磁粉量と漏洩磁束密度の関係を明らかに した。得られた結果を以下にまとめる。

（1）磁粉付着過程の動画像計測から，深いき裂ほ ど磁粉幅の増加する速度は速いことが確認された。ま た, 最終的にき裂に付着する磁粉幅および高さは, 両 者ともき裂の深さと比例関係にあり, 磁粉幅と高さか らき裂深さを推定する関係式を求めた。

（2）実験で用いた試験鋼板の正確な $B-H$ 曲線を, 実験と解析における漏洩磁束密度の比較により決定し た。この $B-H$ 曲線を用いた数值解析により, 実験では 測定が困難である微小き裂からの微量な漏洩磁束密度 を，正確且つ詳細に評価できることを確認した。
（3）き裂に付着する磁粉量と，き裂からの漏洩磁 束密度の強度および傾きの関係を評価し, それらは比 例関係にあることを確認した。

今後は, き裂の幅および長さをパラメータとして検 討し, き裂形状, 付着磁粉量および漏洩磁束密度の関 係を把握できるデータベースを構築する予定である。 これにより, 複雑な形状をした自然き裂に適用可能 な定量的評価システムの確立を目指す。

本研究の一部は, 科研費 (24560889) および平成 23-24 年度 JST (FS ステージ)「シーズ顕在化タイプ」の研 究助成を受け実施したものである。

(2014 年 1 月 27 日受付)

\section{参考文献}

[1] 日本非破壊検査協会編 : 磁粉探傷試験 I III, 日 本非破壊検查協会.

[2] N.Kasai, A.Takada, K.Fukuoka, H.Aiyama and M.Hashimoto, Quantitative investigation of a standard test shim for magnetic particle testing, NDT\&E International 44, pp.421-426, 2011.

[3] 福岡克弘, 川越一平, 磁粉探傷試験におけるき裂 定量評価の検討, 電気学会, 平成 24 年基礎・材料・ 共通部門大会, p.231, 2012.

[4] 川越一平, 福岡克弘, 作田健, 磁粉探傷試験にお ける久陥形状の定量的評価手法の検討，日本非破 壊検查協会, 平成 24 年度春季講演大会, pp.65-66, 2012.

[5] K.Fukuoka, I.Kawagoe, Evaluation of magnetic particle amount and leakage flux density for quantitative evaluation of crack shape in magnetic particle testing, Abstract Book of the 16th edition of the International Symposium on Applied Electromagnetics and Mechanics, pp.263-264, 2013.

[6] 福岡克弘, 川越一平, 磁粉付着過程の動画像計測 とき裂形状による漏洩磁束密度分布の評価, 日本 非破壊検查協会, 第 15 回表面探傷シンポジウム講 演論文集, pp.3-6, 2012. 